\title{
WEB-BASED EQUIPMENT INVENTORY INFORMATION SYSTEM IN THE SERVICE DIVISION OF PT ARISTA SUKSES MANDIRI JAKARTA
}

\author{
Anggi Oktaviani ${ }^{*}$, Muhammad Nogie ${ }^{2}$, Deny Novianti ${ }^{3}$ \\ Sistem Informasi \\ STMIK Nusa Mandiri \\ www.nusamandiri.ac.id \\ anggi.aov@nusamandiri.ac.id 1*; muhammad.nogie@nusamandiri.ac.id ${ }^{2}$ \\ Sistem Informasi \\ Universitas Bina Sarana Informatika \\ www.bsi.ac.id \\ denynov.dov@bsi.ac.id ${ }^{3}$ \\ $\left(^{*}\right)$ Corresponding Author
}

\begin{abstract}
Abstrak
Manajemen inventaris peralatan kerja pada divisi service PT. Arista Sukses Mandiri Jakarta masih dilakukan secara manual mengguakan form cetak (untuk dailycheck) dan buku tulis tangan (yang mencatat setiap peralatan yang masuk dan/atau keluar gudang), oleh karenanya para personil membutuhkan waktu yang lebih lama untuk melaksanakan kegiatan tersebut. Pengelolaan inventaris peralatan harus benar dan tepat antara data yang ada dan kenyataannya di lapangan, tetapi apabila dilaksanakan secara manual resiko dari kesalahan data lebih tinggi dibandingkan apabila dilaksanakan menggunakan sistem terkomputerisasi. Selain itu, menggunakan sistem terkomputerisasi dalam lingkungan inventaris peralatan bisa menjadikan prosesnya lebih cepat, sehingga efisiensi waktu bisa tercapai. Sistem inventaris berbasis web dikembangkan oleh penulis (sekaligus pengembang) untuk mengatasi atau setidaknya mengurangi masalah tersebut. Model yang digunakan dalam pengembangan sistem aplikasi berbasis web ini adalah model pengembangan waterfall dengan pusaran air (whirlpools) untuk pemula seperti yang disarankan oleh Powel, dkk. Model ini terdiri dari definisi masalah, analisa kebutuhan, desain prototipe, implementasi, integrase/pengujian, rilis/pemeliharaan.Produk akhir dari penelitian dan pengembangan yang tertulis dalam tulisan ini adalah aplikasi berbasis web untuk inventaris peralatan kerja yang dapat menjadikan prose tersebut lebih cepat, tepat dan efisien.
\end{abstract}

Kata kunci: Sistem Inventory; Sistem Informasi; Model Waterfall

\begin{abstract}
Work equipment inventory management at the service division of PT. Arista Sukses Mandiri Jakarta is still done manually using printed forms (for daily checks) and handwritten books (which record every piece of equipment that enters and/or leaves the warehouse), therefore personnel needs more time to carry out these activities. Equipment inventory management must be correct and precise between existing data and the reality in the field, but if it is carried out manually the risk of data error is higher than if it is carried out using a computerized system. Also, using a computerized system in an equipment inventory environment can make the process faster, thus achieving time efficiency. The web-based inventory system was developed by the author (as well as the developer) to solve or at least reduce the problem. The model used in the development of this web-based application system is a waterfall development model with whirlpools for beginners as suggested by Powel et al. This model consists of problem definition, needs analysis, prototype design, implementation, integration/testing, release/maintenance. The final product of research and development written in this paper is a web-based application for work equipment inventory that can make the process faster, precise, and efficient.
\end{abstract}

Keywords: Inventory System; Information System; Waterfall Model

\section{INTRODUCTION}

With advances in computer technology that are increasingly rapid, many are used to facilitate human work. One of them is in the field of recording inventory. Information technology and management are now starting to be used in the field of education, one of which is marked by the 
existence of schools that have implemented computer technology for data processing, but the application of information technology and computers has not been widely applied. (Oktaviani et al., 2019). The use of information technology is currently growing rapidly in all fields of education or companies. This process changes the system from manual to computerized. One of them is the company's inventory system (Sari, 2017). In the business world, records have always been a common practice because, without these activities, business processes would not run properly. This is proven by the fact that many agencies and companies have used computers equipped with useful application programs to facilitate work to be more effective and efficient (Hakim et al., 2019). Inventory or often called inventory is the storage of raw, material, or finished goods that are stored for future use or within a certain period. (Heryanto et al., 2014). Inventory of goods is the recording of data relating to goods or assets in the organization. In general, the activities in the inventory of goods are recording the procurement of goods, placement, transfer, and maintenance (Susandi \& Sukisno, 2018). Each organization is obliged to carry out an inventory of state property which is controlled by their respective offices in an orderly, complete, and orderly manner (Khusnah \& Purwanto, 2017). In general, activities in the inventory of goods include data collection on procurement, placement, and maintenance, as well as reporting (Sataria \& Siahaan, 2018). PT Arista Sukses Mandiri is one of the companies that carry out equipment inventory recording activities (tools and special service tools), in addition to other records. This activity is carried out to check and control the availability of equipment that supports operational activities, namely the service division. The personnel who are responsible for data collection and recording activities are tool men and technicians in the field. A web-based information system is a combination of information technology based on a site on the internet network that is equipped with features and is designed in such a way as to the need for inputting certain data aims to simplify and speed up the processed data even though the user is a beginner. (Setioardi \& Sukisno, 2019). The purpose of this research is to design a web-based equipment inventory information system as a solution to problems arising from manual data processing. By changing the system to be computerized, it is hoped that inventory management will be more effective and efficient, and the presentation of inventory reports will be more accurate and timely. (Sari, 2017).

\section{RESEARCH METHODS}

\section{Types of research}

This study uses a qualitative research method approach because qualitative research emphasizes the research process rather than the results, meaning that if the research process is appropriate then the results will automatically be valid. So that the main purpose of qualitative research is to provide an understanding (to understand) of the social phenomenon or phenomenon that is being studied (Arios, 2011).

\section{Time and Place of Research}

This research was conducted in February April 2020 at PT Arista Sukses Mandiri Jakarta.

\section{Research Target / Subject}

The target of this research is to increase the work efficiency of employees, namely in the service division thanks to a system that can help the work of recording tool inventories, as well as simplifying the work of tool men and technicians and other personnel involved in recording activities or tool inventory data collection with a system designed and run.

\section{Data, Instruments, and Data Collection Technique}

The research method consists of data collection techniques and a system development model which will be described in the sub-chapters below:

a. Observation Conducting direct observations of the current incentives system at Pt Arista Sukses Mandiri Jakarta, which is addressed to JL. Gajah Mada No.18, Gambir District, Central Jakarta.

b. Interview Conduct direct questions and answers with Mr. Mahmud Badarudin, as the administrative division who directly manages the inventory in the company.

c. Literature Study Literature study is carried out by gathering information relevant to the tooling inventory system either through printed books or e-books or online journals.

\section{System Development Model}

The research method aims to understand phenomena by describing facts, proving, developing, and discovering knowledge. Research objects and problems do influence considerations regarding the approach, design, or research method to be applied (Mulyadi, 2011). One of the research methods is the action research method, which is a research method used to test, develop, 
discover and create new actions, so that if these actions are applied to work, the work implementation process will be easier, faster, and the results are more and more. quality (Sugiyono, 2008). The waterfall model provides a sequential or sequential approach to the software life flow starting from the analysis, design, coding, testing, and support stages (support) (Dermawan \& Hartini, 2017).

System development is carried out in sequence starting from analysis, design, coding, testing, and support stages (Firmansyah \& Udi, 2017). Meanwhile, according to Winston Royce, the Waterfall method is a sequential software development process, in which progress is seen as continuing to flow downward (like a waterfall) through the phases of planning, modeling, implementation (construction), and testing. In its development, the waterfall method has several coherent stages: requirements (needs analysis), system design (system design), Coding \& Testing, Program Implementation, maintenance (Tristianto, 2018). The waterfall model provides a sequential or sequential software life flow approach starting from the analysis method, design method, coding method, testing, and support stage methods (Lesmono, 2019). The following is an explanation of the five stages of the model:

1. Software Requirements Analysis

At this stage, an exploration of the needs of the user is carried out. This academic information system will be implemented on a web-based system because this web-based system is easily accessible anywhere.

2. Design

After the need for the development of academic information systems has been identified, a system design will be carried out. Database design uses Entity-Relationship Diagram (ERD), Logical Record Structure (LRS), and for system design using Unified Modeling Language (UML).

3. Code Generation (Encoding)

The process of making coding or coding is the translation of the design into a language that can be recognized by the computer, the programming languages used are PHP, HTML, CSS, and JavaScript and database. The author uses bootstraps with dynamic web display features and User Friendly.

4. Testing

The most suitable testing technique for testing web-based academic information systems User Acceptance Testing (UAT) so if the test results are considered to meet the needs of the user, the application can be applied.

5. Support
In supporting the information system to be worked on, the hardware is needed, namely equipment in physical form that runs the software (software), and this equipment functions to carry out instructions given and issue it in the form of information.

\section{Data Analysis Technique}

Based on documents obtained by the author while researching PT Arista Sukses Mandiri Jakarta, input and output documents and other supporting documents were obtained. Once everything is checked and categorized, a database design will be created that will be used in storing, calling, and displaying the results of data processing to be processed by the software and as a design to make it easier to design applications using the Unified Modeling Language (UML).

\section{RESULTS AND DISCUSSION}

\section{A. Software Requirements Analysis}

The designed system allows administrators to manage tool man data and technician data. Technicians have the authority to manage tool data (either SST or Common Tools), tool borrowing transactions, and daily checks (SST only).

Meanwhile, technicians can carry out equipment borrowing transactions and fill in daily check data on work tools received by each technician group.

\section{Administrator Function}

\section{A.1. Administrators can log in}

A.2. Administrators can manage group data

A.3. Administrators can manage tool data

A.4. Administrators can manage reports

\section{The Toolman Function}

\section{B.1. Toolman can log in}

B.2. Toolman can manage tool distribution

B.3. Toolman can manage tool borrowing

B.4. Toolman can fill in the daily check.

\section{Technician Function}

C.1. Technicians can log in

C.2. Technicians can borrow equipment

C.3. Technicians can borrow tools

\section{B. Design}

1. Designing Software Systems

This design stage is the stage of defining the process and system requirements, starting from database design, software architecture, user interface, code generation, testing, and support. The following are the designs in this study: 


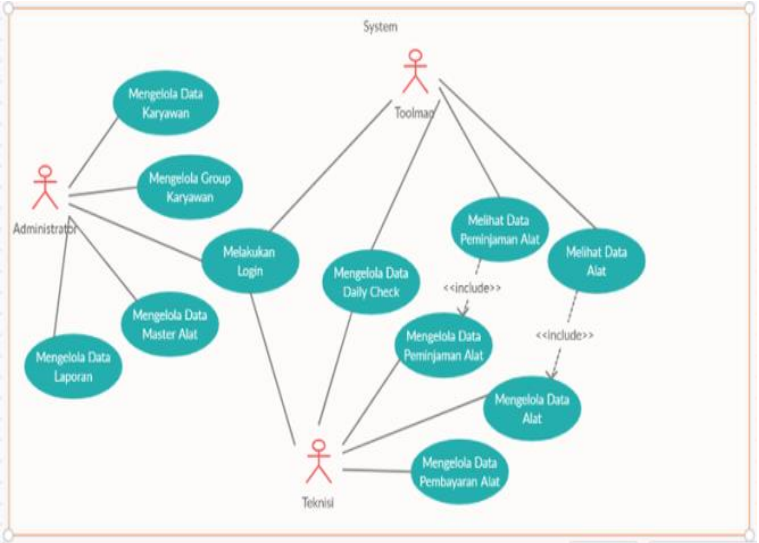

Figure 1. Use Case Diagram Administrator Page

Table 1. Use case login description

\begin{tabular}{|c|c|}
\hline Use Case Name & Doing Log On \\
\hline Requirements & A1 \\
\hline Pre-Conditions & $\begin{array}{l}\text { Users can log on to the system as } \\
\text { an administrator }\end{array}$ \\
\hline Post-Conditions & $\begin{array}{l}\text { The user has accessed the login } \\
\text { page }\end{array}$ \\
\hline Failed end & 1. The user presses the login \\
\hline Conditions & $\begin{array}{l}\text { button without filling in the } \\
\text { required fields (User ID and } \\
\text { password) or the user pressing } \\
\text { the login button with input fields } \\
\text { that are not registered / suitable } \\
\text { as an administrator. } \\
\text { 2. Exit the system by any means } \\
\text { such as going to another website } \\
\text { or closing tabs and/or browsers. }\end{array}$ \\
\hline Primary Actors & Administrator \\
\hline $\begin{array}{l}\text { Main Flow / Basic } \\
\text { Path }\end{array}$ & $\begin{array}{l}\text { 1. The user accesses the login } \\
\text { page. }\end{array}$ \\
\hline & $\begin{array}{l}\text { 2. User fills in the input text for } \\
\text { the correct User ID and password } \\
\text { respectively. } \\
\text { 3. The user presses the login } \\
\text { button. } \\
\text { 4. The system displays a home } \\
\text { page for the administrator. }\end{array}$ \\
\hline Invariant A & $\begin{array}{l}\text { A.4. Users who have successfully } \\
\text { logged in as administrators click } \\
\text { on one of the following menus: } \\
\text { Personnel Data, Personnel Group } \\
\text { Data, Tool Masters, Reports. } \\
\text { A.5. The system displays another } \\
\text { selected menu. }\end{array}$ \\
\hline
\end{tabular}

2. Database Systems

The design of the main database using the Entity-Relationship Diagram (ERD), by identifying the types of entities and attributes.

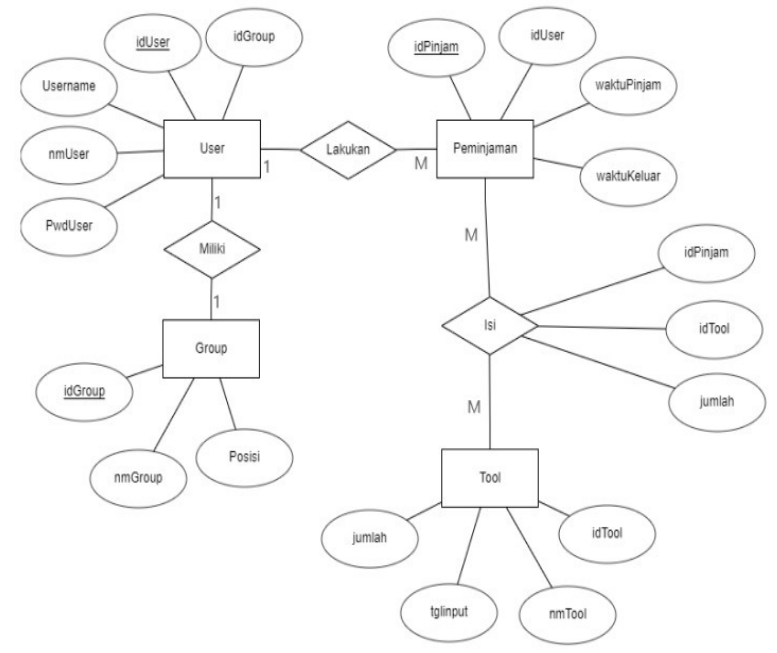

Figure 2. Entity Relationship Diagram (ERD) Inventory System

Entity Relationship Diagram is to explain the relationship between data in a database.

LRS (Logical Record Structure) is a representation of the structure of records in tables that are formed from the results between sets of entities. (Sukmaindrayana \& Sidik, 2017). The following is a display of the Logical Record Structure as shown in Figure 3 below.

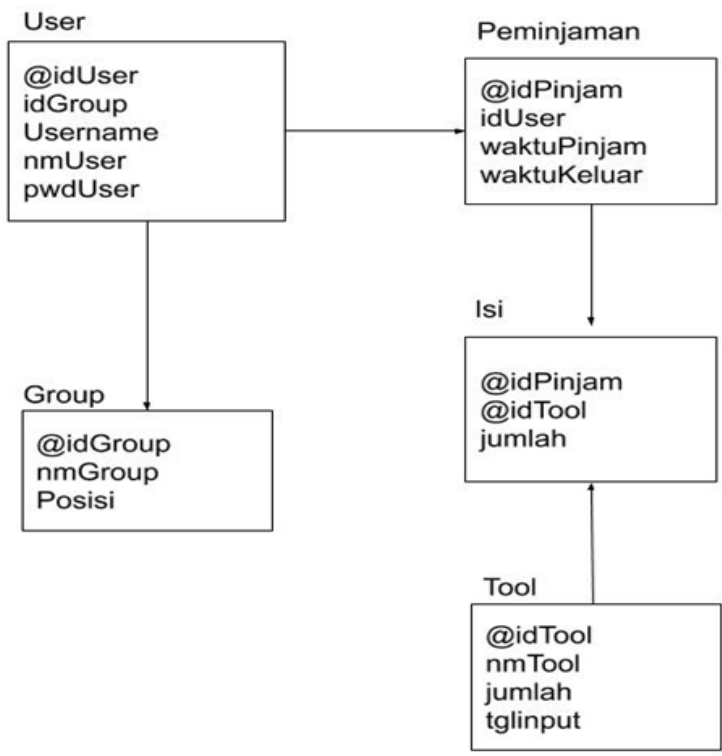

Figure 3. Logical Record Structure (LRS) Inventory System

Logical Record Structure (LRS) serves to show the logical flow of a record.

3. Navigation Design

a. Navigation Administration Page 


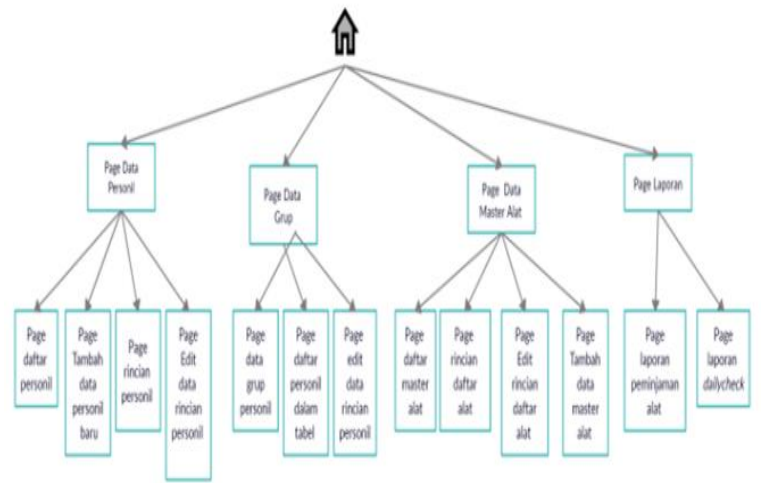

Figure 4. Navigation Administration Page

Figure 4 describes the menu flow that can be selected on the administrator page.

4. User Interface Design

a. Interface Form Login

Figure 5 illustrates the login page to enter data correctly to access the system.

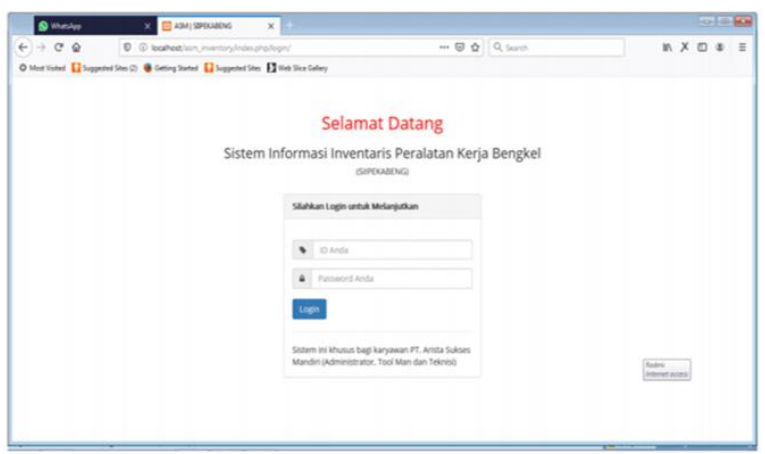

Figure 5. Interface Form Login

\section{b. Interface Form Admin}

Figure 6 illustrates the interface displayed for admin. Here the admin can manage personnel data, manage group data, manage tool master data, and manage reports.

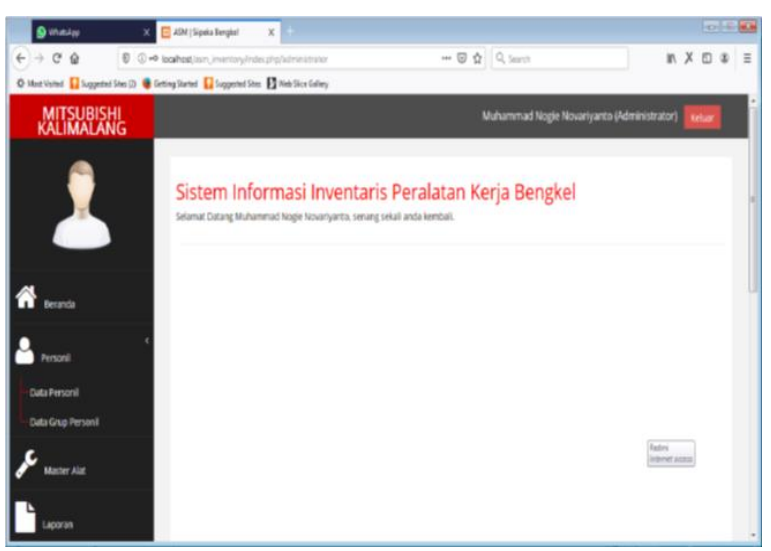

Figure 6. Interface Form Admin c. Interface Form Grup Personil

Figure 7 illustrates the interface of the personnel group form. Where admin can add personnel group data, view the personnel list in the table, and edit the personnel details data.

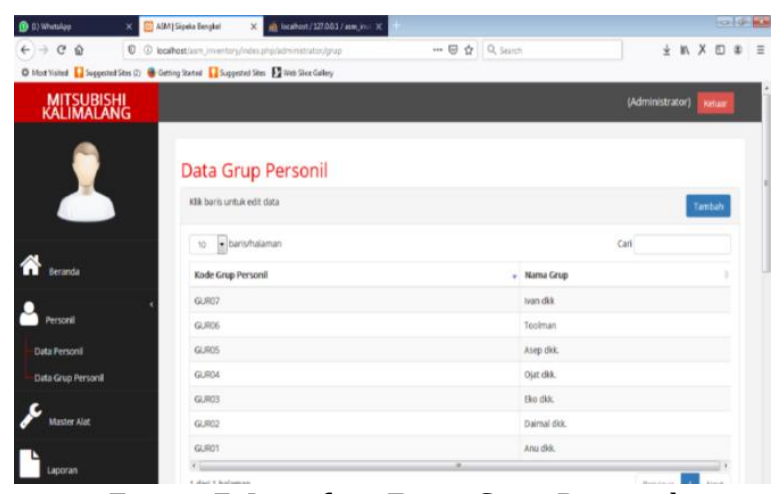

Figure 7. Interface Form Grup Personil

d. Interface Form Laporan

Figure 8 describes the interface of the report form. Where the admin can manage reports of lending tools and daily check reports.

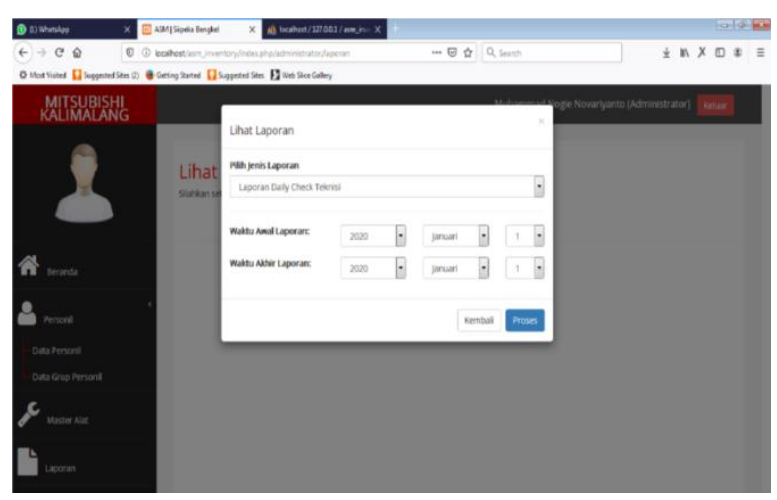

Figure 8. Interface Form Laporan

\section{Software Code}

1. Code Class Tool_M

$<$ ?php

class Tool M extends CI Model

function getAlitool (\$param) \{

\$this->db->select

('idTool, user.nmUser, tool.idMaster, nmTool, jml

Tool, tool.tglinput, master_tool.kategori');

\$this->db->join

('master tool', 'master tool.idMaster =

tool.idMaster', 'inner';

\$this->db->join('user', 'user.idUser =

tool.idUser');

if (\$param !=0 || \$param !=false || \$param

!= NULL || \$param != "") \{

foreach (\$param as $\$$ key $=>$ \$value) \{

if (\$key == 'tool.jmlTool' || \$key ==

'tool grup.jmlTool') \{

\$this->db->where (\$key . '>', \$value);

\} else \{

\$this->db->where (\$key, \$value); \} \}

\$this->db->order_by('idTool DESC'); 


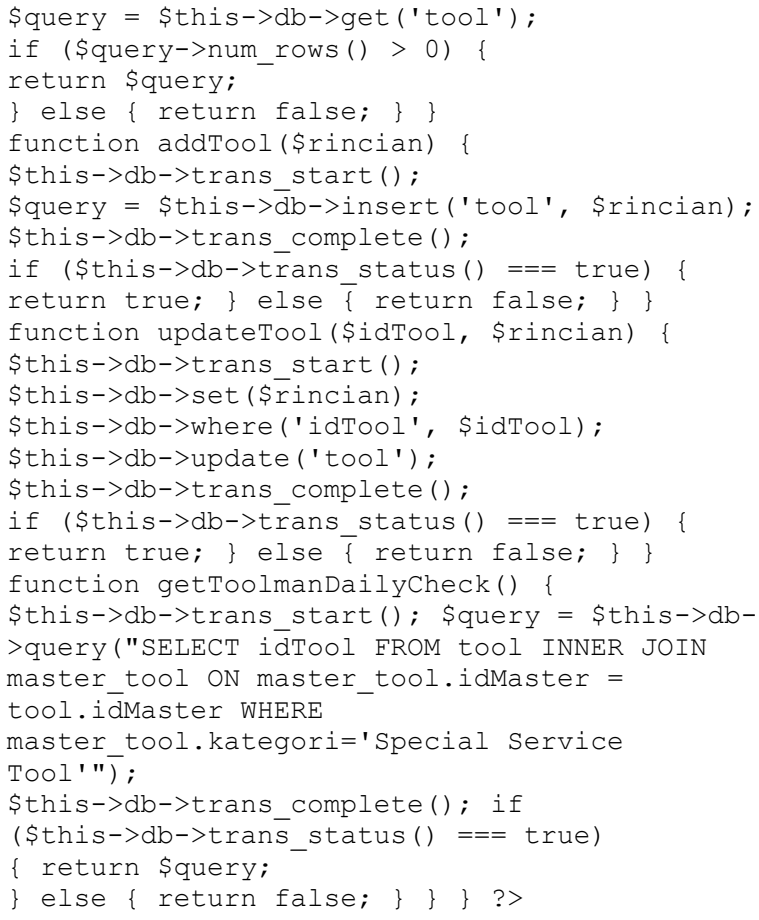

\section{Software Testing}

User Acceptance Test (UAT) is a process of testing by users which is intended to produce documents that serve as evidence that the system being developed is acceptable or not by the user, if the test results are considered to meet the needs of the user, the application can be applied (Pangistu et al., 2019).

Testing of programs that use UAT that focus on the process of program input and output. Testing with UAT is done by asking several questions to users, this test involves 15 users. User acceptance test results are assessed from 5 categories, namely A (Very Good), B (Good), C (Fair), D (Not Good), and E (Not Good). Following are the details of the results in Table 1.The following:

Tabel 2. UAT Testing

\begin{tabular}{|c|c|c|c|c|c|c|}
\hline \multirow[t]{2}{*}{ No } & \multirow[t]{2}{*}{ Question } & \multicolumn{5}{|c|}{ Response } \\
\hline & & $\mathbf{A}$ & B & C & D & $\mathbf{E}$ \\
\hline 1 & $\begin{array}{l}\text { Is the appearance of } \\
\text { the Inventory } \\
\text { Information System } \\
\text { Website Attractive? }\end{array}$ & 10 & 4 & 1 & 0 & 0 \\
\hline 2 & $\begin{array}{l}\text { Are the menus on } \\
\text { this website easy to } \\
\text { understand? }\end{array}$ & 8 & 5 & 2 & 0 & 0 \\
\hline 3 & $\begin{array}{l}\text { Are the buttons on } \\
\text { the website easy to } \\
\text { understand? }\end{array}$ & 10 & 3 & 2 & 0 & 0 \\
\hline 4 & Does this website & 10 & 4 & 1 & 0 & 0 \\
\hline
\end{tabular}

\begin{tabular}{lllllll}
\hline No & \multicolumn{1}{c}{ Question } & \multicolumn{6}{c}{ Response } \\
\cline { 2 - 7 } & A & B & C & D & E \\
\hline & $\begin{array}{l}\text { help in the process } \\
\text { of recording } \\
\text { inventory systems? }\end{array}$ & & & & & \\
$\mathbf{5} \quad \begin{array}{l}\text { Does this website } \\
\text { help you find the } \\
\text { information you } \\
\text { need? }\end{array}$ & 10 & 3 & 2 & 0 & 0 \\
$\mathbf{6} \quad \begin{array}{l}\text { Is the entire website } \\
\text { easy to understand? } \\
\text { Is } 10\end{array}$ & 4 & 1 & 0 & 0 \\
this website & 10 & 3 & 2 & 0 & 0 \\
\hline good? & 68 & 26 & 11 & 0 & 0 \\
\hline
\end{tabular}

From the recapitulation of all respondents' answers which can be seen in Table 1. The majority of respondents have a positive opinion with a very good number of answers of 68 . There are only 11 answers that say the website is good enough. So it can be concluded that the Inventory Information System web application can be accepted by users to speed up the inventory recording process.

\section{Conclusion}

The equipment inventory information system can be applied to the service division of PT. Arista Sukses Mandiri in managing work equipment inventory in the workshop environment. Equipment information and data are easier to access because of the integrated database system. It is easy to get detailed tools related to conditions, location, and availability thanks to the daily check feature and borrowing transactions, and equipment distribution. Each personnel is facilitated in the codification process both tool codification, tool borrowing transactions, and others thanks to the automatic codification that can be done by the system. Ease for assessment in managing report data. The system being developed is still vulnerable to security.

Filling in several forms on the web is still ineffective because some forms do not yet support multi-values (one form can fill in more than 1 (one) item) From UAT testing can be concluded that the Inventory Information System web application can be accepted by users to speed up the inventory recording process.

\section{Suggestion}

Implementation of data backup for the system administrator needs to be done so that if an error occurs, data recovery can be carried out. Personnel training in the use of this web application tool inventory information system 
needs to be done by the management of PT. Arista Sukses Mandiri so that the use of the new system can run smoothly and have the expected results. It is necessary to make a manual book and documentation as detailed as possible both in the use of the application system for each user level and in terms of system maintenance. For this application to run smoothly as it should, the optimal hardware and software specifications need to be prepared by the relevant management. Use on a mobile phone device (cellphone) or tablet pc should be done in an elongated position (landscape) so that the web layout is more optimal. IP address settings on the webserver need to be done to reach client devices that have the right to access the equipment inventory information system being implemented. Given the importance of data security, further, development needs to pay more attention to security.

\section{REFERENCES}

Arios, R. L. (2011). Berbagai Tipe Penelitian Kualitatif: Masihkah Diperlukan? Kompasiana.Com.

c/ephineogi.blogspot.com/5508efa5813311 5e1cb1e202/berbagai-tipe-penelitiankualitatif-masihkah-diperlukan

Dermawan, J., \& Hartini, S. (2017). Implementasi Model Waterfall Pada Pengembangan Berbasis Web Pada Sekolah Dasar Al-Azhar Syifa Budi Jatibening. Paradigma, 19(2), 142147.

https://ejournal.bsi.ac.id/ejurnal/index.php/ paradigma/article/view/2131

Firmansyah, Y., \& Udi, U. (2017). Penerapan Metode SDLC Waterfall Dalam Pembuatan Sistem Informasi Akademik Berbasis Web Studi Kasus Pondok Pesantren Al-Habib Sholeh Kabupaten Kubu Raya, Kalimantan Barat. Jurnal Teknologi Dan Manajemen Informatika, https://doi.org/10.26905/jtmi.v4i1.1605

Hakim, Z., Sakuroh, L., \& Awaludin, S. (2019). Sistem Informasi Persediaan Barang Berbasis Web Pada CV Telaga Berkat. Jurnal Sisfotek Global, 9(1), 69-74.

Heryanto, A., Fuad, H., \& Dananggi, D. (2014). Rancang Bangun Sistem Informasi Inventory Barang Berbasis Web Studi Kasus di PT. Infinetworks Global Jakarta. Sisfotek Global, $4(2)$, 32-35. https://journal.stmikglobal.ac.id/index.php/ sisfotek/article/view/48

Khusnah, B., \& Purwanto, P. (2017). Pelaksanaan
Inventarisasi Barang Milik/Kekayaan Negara Di Kantor Komisi Pemilihan Umum (KPU) Kabupaten Kulon Progo. Jurnal Pendidikan Administrasi Perkantoran, 6(2), 167-176. http://journal.student.uny.ac.id/ojs/ojs/inde x.php/adp-s1/article/view/8747

Lesmono, I. D. (2019). Animasi Berbasis Multimedia Untuk Siswa Berupa Pengenalan Moda Transportasi Dengan Metode Waterfall. Swabumi, 7(1), 20-30. https://doi.org/10.31294/swabumi.v7i1.557 2

Mulyadi, M. (2011). Penelitian Kuantitatif Dan Kualitatif Serta Pemikiran Dasar Menggabungkannya. Jurnal Studi Komunikasi Dan Media, 15(1), 128-137. https://doi.org/10.31445/jskm.2011.15010 6

Oktaviani, N., Nurlaily, \& Widiarta, I. M. (2019). Sistem Informasi Inventaris Barang Berbasis Web Pada Smp Negeri 1 Buer. Jurnal JINTEKS, 1(2), 160-168.

Pangistu, L. A. M., Azhari, A., \& Aktawan, A. (2019). Visualisasi Informasi Website International Conference Berdasarkan Web-Quality Framework. Mobile and Forensics, 1(2), 31. https://doi.org/10.12928/mf.v1i2.1282

Sari, A. O.; E. N. (2017). Rancang Bangun Sistem Informasi Persediaan Barang Berbasis Web Dengan Metode Fast(Framework For The Applications). Jurnal PILAR Nusa Mandiri, Vol. 13, $N(2), 261-266$.

Sataria, I., \& Siahaan, K. (2018). Analisa Dan Perancangan Sistem Informasi Inventarisasi Barang Milik Negara (BMN) Kantor DPD RI Di Ibukota Provinsi Berbasis Web Pada Sekretariat Jenderal DPD RI. Jurnal Manajemen Sistem Informasi, 3(3), 1120$1129 . \quad$ http://ejournal.stikomdb.ac.id/index.php/manajemensisteminform asi/article/view/473

Setioardi, M. A., \& Sukisno. (2019). Perancangan Sistem Informasi Pengelolaan Barang Inventaris Berbasis Web Di SMAN 24 Kabupaten Tangerang. Jutis (Jurnal Teknik Informatika, 7(1), 29-35. http://ejournal.unis.ac.id/index.php/jutis/ar ticle/view/144

Sugiyono. (2008). Metode Penelitian Kuantitatif, Kualitatif, dan $R \& D$. CV. Alfabet.

Sukmaindrayana, A., \& Sidik, R. (2017). Aplikasi Grosir Pada Toko RSIDIK Bungursari Tasimalaya. Jurnal Manajemen Informatika, 4(2), 31-40.

Susandi, D., \& Sukisno, S. (2018). Sistem Informasi Inventaris Berbasis Web di Akademi 
Kebidanan Bina Husada Serang. JSiI (Jurnal Sistem Informasi), 5(2), 46-50. https://doi.org/10.30656/jsii.v5i2.775

Tristianto, C. (2018). Penggunaan Metode Waterfall Untuk Pengembangan Sistem Monitoring Dan Evaluasi Pembangunan Pedesaan. ESIT Jurnal Teknologi Informasi, 12(1), 8-22. http://jurnaleresha.ac.id/index.php/esit/article/view/51 